\title{
Improvement of Bovine Pestiviral diagnosis by the development of a cost-effective method for detecting viral RNA in fresh specimens and samples spotted in filter papers.
}

Paula Melisa Favaro ( $\square$ pfavaro@fcv.unl.edu.ar)

Universidad Nacional del Litoral Facultad de Ciencias Veterinarias https://orcid.org/0000-0001-5518$313 \mathrm{X}$

\section{Ana Molineri}

Instituto Nacional de Tecnologia Agropecuaria

Maria J. Dus Santos

Instituto Nacional de Tecnologia Agropecuaria

Luis F. Calvinho

Instituto Nacional de Tecnologia Agropecuaria

Andrea Pecora

Instituto Nacional de Tecnologia Agropecuaria

\section{Research Article}

Keywords: Bovine pestiviruses, diagnosis, filter papers, RT-qPCR

Posted Date: February 15th, 2022

DOI: https://doi.org/10.21203/rs.3.rs-1068751/v2

License: (c) (i) This work is licensed under a Creative Commons Attribution 4.0 International License.

Read Full License 


\section{Abstract}

Bovine pestiviruses are the causative agents of Bovine viral diarrhea, a disease that generates severe economic losses in cattle. The aim of this study was to improve its diagnosis by means of developing a RT-qPCR to detect bovine pestiviruses $\mathrm{A}, \mathrm{B}$ and $\mathrm{H}$; and to set a protocol for collecting, shipping and conserving bovine pestiviral RNA in filter papers. The developed RT-qPCR showed high sensitivity in detecting these viruses in different matrixes: viral stocks, semen and serum samples. Regarding the possibility of using the technique to test serum pools, it was possible to identify a positive serum sample within a pool containing 30 sera. In addition to evaluating the qPCR from fresh samples, the use of filter papers to sow bovine samples was analyzed. The sampling method in two different filter papers using bovine blood drops was a useful alternative for diagnosis purposes and allowed the preservation of pestiviral RNA up to 12 months under refrigeration.

\section{Introduction}

Bovine pestiviruses produce severe economic losses in cattle worldwide. Pestiviruses belong to the family Flaviviridae, and are single-stranded RNA viruses, classified into the genus Pestivirus, also including Pestivirus C (Classical swine fever virus) and Pestivirus D (Border disease virus) (Valley, 2017). Two species of bovine pestiviruses (also known as Bovine viral diarrhea virus) are known, Pestivirus $A$ and Pestivirus $B$ (previously known as BVDV-1 an BVDV-2, respectively) (Smith et al., 2017). Few years ago, an emerging bovine pestivirus was found (Schirrmeier et al., 2004), and it was recently classified as Pestivirus H (Smith et al., 2017). Within each genotype, there are two biotypes, called cytopathic (CP) and not cytopathic (NCP), according to the ability to cause damage in cell cultures (Littledike et al., 1993).

Bovine pestiviruses can be transmitted to susceptible animals through all secretions from an infected animal. Persistently infected animals $(\mathrm{Pl})$ have a fundamental role in the transmission of the virus since they are the main source of infection through their fluids to their cohabitants. They acquire the viral infection through placenta during pregnancy with a NCP strain. From days 45 to 125 of pregnancy the immune system of the fetus is not developed, so it is incapable to produce a proper immune response. Infection in this period of time leads to development of a PI and seronegative calf (Rondón, 2006). Thus, $\mathrm{PI}$ animals spread virus through their secretions and excretions lifelong.

Pestiviruses $A, B$ and $H$ are the causative agents of Bovine viral diarrhea (BVD), which includes a wide range of syndromes, including diarrhea, respiratory disease, reproductive failures, embryonic mortality, abortions, malformations and hemorrhagic syndromes, depending on the age of the host and the viral strain. In addition, in $\mathrm{PI}$ animals, bovine pestiviruses can cause a severe syndrome called Mucosal Disease when they are re-infected with a CP strain of the virus (Lértora, 2003).

Identification and elimination of PI animals is essential for the control of BVD in infected herds. Furthermore, application of biosecurity measures, such as testing all animals arrived to the herd, testing semen, avoiding the contact with neighboring herds, controlling other species that could host the virus, among others, is necessary to prevent the reintroduction of pestiviruses in the herd (Ståhl and Alenius, 
2012). In some European countries, eradication of bovine pestiviruses was accomplished by applying the mentioned biosecurity measures, including or not vaccination programs (Moenning and Becher, 2015).

Detection of $\mathrm{PI}$ animals requires the use of direct diagnosis techniques. Among the available assays, viral isolation is the gold standard test, but it is expensive and takes several days to yield results, whereby it is currently disused in most diagnostic laboratories. Other techniques can be used to detect viral antigens, such as enzyme linked immunosorbent assays, direct immunofluorescence and immunohistochemistry. As an alternative, end point polymerase chain reaction with retro-transcription (RT-PCR) and quantitative RT-PCR (RT-qPCR) detects viral RNA with high sensitivity (Sandvik, 1999). qPCR has several advantages, such as fastness, and the possibility to pool samples from different animals (Dubovi, 2013). Once the pools have been checked by RT-qPCR, if one of them is positive, it has to be split, and each sample must be tested individually. Comparing with individual testing, the chance to test several animals as a pool is a great advantage in herds with low BVD prevalence, taking into account the saving of reagents and time consumed by technicians. Several strategies to pool samples according to the prevalence of BVD in herds have been proposed (Muñoz-Zanzi et al., 2000). Currently, there are commercial in vitro diagnostic RTqPCR kits available that assure the detection of a bovine pestivirus positive animal within a pool of 50 samples; however, they may be inaccessible in some low-income countries because of their price and importation difficulties.

One of the critical points for molecular diagnostics is the correct sample preservation. As bovine pestiviruses are very labile RNA viruses (Valley, 2017), a cold chain must be ensured to avoid erroneous results in a RT-qPCR assay; therefore, samples must be taken and sent chilled to the laboratory as soon as possible. This is an inconvenient in herds located in places far away from the diagnostic laboratories. Blood samples should be maintained at $4^{\circ} \mathrm{C}$ while semen should be sent in liquid nitrogen, which represents high costs and shipping logistics. An useful alternative to improve collecting and shipping samples is filter paper (cotton-based, cellulose paper), such as the Flinders Technology Associates cards (FTA® cards), specially designed to maintain nucleic acids stable at different temperatures and to protect them from UV rays (Sakai et al., 2015). Since microorganisms present in samples spotted onto filter papers are supposed to be immediately inactivated, the FTA system is completely safe and the cards could be shipped by postal mail, at room temperature (RT). FTA cards are widely used in different areas, such as bio-banking, forensic genetics and molecular epidemiology research, since they preserve nucleic acids for long time periods. They have been effective for the detection of RNA viruses (Rabies virus, Newcastle disease virus, Infectious bursal disease virus, and Foot-and-mouth disease virus) (Moscoso et al., 2006; Muthukrishnan et al., 2008; Perozo et al., 2006; Picard-Meyer et al., 2007). This technology is easy to use and non-invasive (Ivanovaa et al., 2017), as a small volume of sample is spotted in a filter paper and venipuncture is not needed.

The aims of this study were to develop and validate a Sybr Green-based RT-qPCR test to assess detection and quantification of all bovine pestiviruses in serum and semen samples and to set up a strategy for collecting, shipping and preserving viral RNA in filter papers for BVD diagnosis and biobanking as a costeffective method. 


\section{Materials And Methods}

\section{Virus, plasmid and clinical samples}

Viral strains. A CP Pestivirus B (isolate vs253) strain cultivated in Madin Darby bovine kidney cells (MDBK) available in the Virology Institute and Innovative Technologies (IVIT) from the Research Center of Veterinary Sciences (CICVyA), INTA Castelar was used as a viral stock to standardize the RT-qPCR and to spike specimens in order to mimic clinical samples.

Semen and serum samples. To detect RNA from bovine sera, blood samples without anticoagulant from healthy animals (pestivirus negative by an in-house validated RT-PCR) were collected and sent to the laboratory at $4^{\circ} \mathrm{C}$. Sera was obtained after five minutes centrifugation at $1,500 \mathrm{xg}$ and then dispensed in sterile $1.5 \mathrm{~mL}$ tubes. The sera tubes were stored at $4^{\circ} \mathrm{C}$ or at $-70^{\circ} \mathrm{C}$ in case the sample was not immediately processed.

To assemble pools, aliquots of the same volume of each bovine serum were mixed in a $1.5 \mathrm{~mL}$ tube. The volume of each serum to be used in a pool was calculated according to the size of the pool, with a final volume of $200 \mu \mathrm{L}$.

To detect viral RNA from semen, $250 \mu \mathrm{L}$ straws of extended semen from healthy animals (pestivirus negative by an in-house validated RT-PCR) were shipped in liquid nitrogen and stored at $-70^{\circ} \mathrm{C}$. All samples were thawed at RT before processing.

Sample preparation. The amount of virus used to spike sera and semen straws was calculated based on expected PI's viral titers (104 TCID 50/mL) determined by many authors (Brock et al., 1998; Meyling and Mikél Jensen, 1988). A titrated Pestivirus $B$ stock was used to spike the samples.

Plasmid. For the qPCR standardization, a plasmid containing the pestiviral 5 'untranslated region ( $5{ }^{\prime}$ UTR) of the viral genome was constructed. Partial 5'UTR of a local Pestivirus A isolate (25366) (obtained by RTPCR) was inserted in a pGemT-easy vector (Promega, USA) following manufacturer's recommendations. Competent Escherichia coli DH5-a strains were used for transformation with the ligation product. Transformation was carried out by thermal shock, following molecular biology standard method (Sambrook and Russell 2006). Plasmid was purified with Wizard Plus SV Minipreps kit (Promega, USA) following manufacturer's instructions. Plasmid identity was confirmed using restriction endonuclease digestion. Finally, the purification product was quantified by Nanodrop 2000 (Thermo Scientific, USA) and the number of copies was calculated.

Clinical samples. 28 clinical samples collected from naturally infected animals that were confirmed positive by viral isolation in cell culture and subsequently direct immunofluorescence were used to ensure the viral RNA detection by the assay. The specimens consisted of 4 intestines, 7 fetuses, 3 nasal swabs, one ocular swab, 2 esophagus, one lung, 2 spleens and 8 blood samples (provided and diagnosed by Laboratorio Azul and Specialized Veterinary Diagnostic Service at INTA Balcarce, Argentina). 


\section{qPCR standardization}

qPCR standardization was performed according to the Minimum Information for Publication of Quantitative Real-Time PCR Experiments (MIQE) guidelines (Bustin et al., 2009).

RNA extraction. RNA extraction was performed with High Pure PCR Template Preparation kit (Roche, Switzerland) following manufacturer's instructions. Positive and negative controls were included, consisting of $200 \mu \mathrm{L}$ of Pestivirus B (isolate vs253) and $200 \mu \mathrm{L}$ of elution buffer, respectively. Obtained RNA was immediately stored at $-70^{\circ} \mathrm{C}$ until processing.

Retro-transcription and qPCR reaction. Retro-transcription and qPCR reactions were carried out simultaneously using iTaq Universal SYBR Green One-Step Kit (Bio-Rad, USA). A $10 \mu \mathrm{L}$ final volume mix was prepared with $5 \mu \mathrm{L}$ of iTaq Universal SYBR Green reaction mix, $0.125 \mu \mathrm{L}$ of iScript reverse transcriptase, $0.25 \mu \mathrm{L}$ of forward and reverse primer (Genbiotech, Argentina), $2.625 \mu \mathrm{L}$ of nuclease free water (Biodynamics, Argentina) and $2 \mu \mathrm{L}$ of RNA obtained in previous step. The cycling program consisted in: 10 minutes at $50^{\circ} \mathrm{C}$ for reverse transcription reaction, 1 minute at $95^{\circ} \mathrm{C}$ for polymerase activation and DNA denaturation, followed by 40 cycles of 15 seconds at $95^{\circ} \mathrm{C}$ and 1 minute at $60^{\circ} \mathrm{C}$, finalizing with a $0.5^{\circ} \mathrm{C}$ increment from 65 to $95^{\circ} \mathrm{C}$ every 2 seconds, using StepOne equipment (Applied Biosystems, USA). In each assay, positive and negative controls were included.

Primer's selection and concentration adjustment. Primer pair 189-389 were used to develop the qPCR

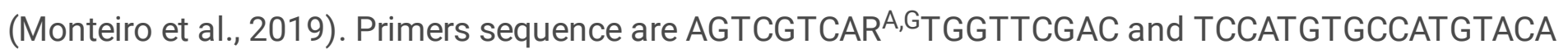
for 189 (forward primer) and 389 (reverse primer), respectively and amplify a 201-nucleotide sequence of the 5'UTR of bovine pestiviral genome. The expected amplicon was verified in BLAST (https://blast.ncbi.nlm.nih.gov/Blast.cgi) and align with reference NADL strain (GenBank accession number M31182) between 190 and 390 positions of the complete sequence.

To establish the most efficient dilution of primers to set up the test, 10 folded dilutions of the plasmid were prepared and several concentrations of primers were assessed $(390 \mathrm{nM}, 420 \mathrm{nM}, 450 \mathrm{nM}, 470 \mathrm{nM}$, $525 \mathrm{nM}, 535 \mathrm{nM}$ and $540 \mathrm{nM}$ ). Primer efficiency was confirmed for each experiment using the formula: Primer efficiency $=10-1 /$ slope $^{18}$ whereby a value of 2.0 indicates $100 \%$ efficiency. This ensured PCR products were amplified at an efficient rate and experiments were comparable among them.

Analytical sensitivity and linear dynamic range of detection. Limit of detection (LOD) was calculated for the different matrixes: plasmid, viral stock (Pestivirus B vs253) and spiked serum and semen. To accomplish that, 10 -fold dilutions were performed, from $10^{9}$ to $10^{0}$ copies of the plasmid and from $10^{5}$ to $10^{0}$ copies of the viral stock, sera and semen. In addition, pools of bovine sera that contained $10,20,30$, 40 and 50 individual samples (one serum of each pool was spiked to mimic a PI sample) were assessed in order to determine the efficiency in pooling sera. The linear range of the qPCR established a standard curve with 10 -fold dilutions of the plasmid from 2.5 to 2,500,000,000 copies. 
Precision. Replication experiments were carried out to test positive controls (plasmid and viral stock) and to compare cycle threshold (CT) results in order to ensure precise detection of the target sequence. CT values of 25 repetitions of viral stock and 10 repetitions of $5^{\prime}$ UTR plasmid were registered. Mean, standard deviation, weighted average variation coefficient (CVpp) and maximum random error allowed (CVa\%) were calculated.

Analytical specificity. Bovine respiratory syncytial virus (BRSV), Bovine parainfluenza-3(PI-3), Bovine herpesvirus-5 (BHV-5), Bovine herpesvirus-1 (BHV-1), Blue tongue virus (BTV), Bovine Rotavirus type $A$ (RVA) and Mycoplasma spp. were used to evaluate the specificity of the test. In addition, several bovine pestiviral stocks available at the IVIT, INTA Castelar, were used to check the ability of the qPCR to detect all possible viral variants. Viral isolates and reference strains included: 13 strains of Pestiviruses $A$ (4 from sub-genotype a and 9 from sub-genotype b), 4 strains of Pestivirus $B$ and 5 strains of Pestivirus $H$.

Inter-laboratory assays. DNA aliquots of plasmid and negative controls, as well as reagents and instructions to run the test were remitted to three different laboratories to perform the qPCR. Two of them were located in the IVIT Institute and other was from a private veterinary diagnostic laboratory. Involved laboratories have trained technicians and separate areas to prepare PCR mixes and sow samples. The assay was also carried out in equipment available at these laboratories: iQ5 (Bio-Rad, USA) ABI7500 (Applied Biosystems, USA) and MyGo (IT-IS Life Science, Ireland) thermal cyclers.

Data analysis. Data analysis was carried out by StepOne Software version 2.3.

\section{Filter paper sample processing}

Storage of contaminated blood spotted in filter papers. Two types of filter papers were used throughout the experiments: FTA cards (Whatman, UK) and cellulose $3 \mathrm{~mm}$ chromatographic paper (GE Healthcare, USA). Since FTA cards are designed for nucleic acids conservation over long time periods, it was used for conservation aims. Conversely, chromatographic paper, commonly used for other purposes and less expensive than the former, was evaluated for rapid laboratory tests in cases of suspected BVD in the field. This means, preserving RNA for shorter periods of time, allowing the collection and shipping of samples to the laboratory at room temperature.

Whole-blood samples were collected from healthy bovines, and then spiked with a titrated Pestivirus $B$ viral stock as previously described so that there were 50,000 copies of RNA in a $50 \mu \mathrm{L}$ drop, according to PI animal viral titers.

Five repetitions of $50 \mu \mathrm{L}$ of spiked blood drops were spotted in chromatographic paper with micropipettes and sterile tips. Then, the drops were dried at RT for four hours and finally stored at RT $\left(15-25^{\circ} \mathrm{C}\right), 4^{\circ} \mathrm{C}$, $-20^{\circ} \mathrm{C}$ and $-70^{\circ} \mathrm{C}$ for one and 7 days and 6,12 and 18 months. The same methodology was performed in FTA cards: 5 drops of spiked blood were spotted for each temperature and stored for 12 and 18 months. The spiked filter papers were stored at different temperatures in zipped bags with desiccant to prevent humidity damage. 
Once storage time expired, RNA was eluted. Briefly, four punches in each blood drop were cut with a $6 \mathrm{~mm}$ puncher and placed in $1.5 \mathrm{~mL}$ tubes containing $220 \mu \mathrm{L}$ of Minimal essential medium (MEM). The tubes were then kept in shaker for 30 minutes at RT and aliquots of $200 \mu \mathrm{L}$ were taken to proceed with RNA extraction and RT-qPCR described above.

In order to prevent cross-contamination among samples and replicates, a protocol recommended in other study was followed. Briefly, puncher was decontaminated between samples by dipping it in isopropyl alcohol for a minute. Later, the puncher was dried with absorbent paper and five punches were cut in a clean, new chromatographic paper (Sarangi et al., 2018).

Limit of detection in filter papers. To assess the LOD in blood, samples were spiked with Pestivirus $B$ at several concentrations and spotted in filter papers. To accomplish that, two replicates of $50 \mu \mathrm{L}$ drops of blood containing $1,000,5,000,10,000,20,000,40,000$ and 80,000 viral particles were spotted in chromatographic paper and later processed as mentioned above.

Recovering RNA from clinical samples. Blood drops of two PI animals were spotted in chromatographic paper, dried up at RT for four hours and then stored at $4^{\circ} \mathrm{C}$ for 1 day and 6, 12 and 18 months. Once storage time expired, samples were processed as previously mentioned.

Statistical analysis. Aiming to compare the efficiency in recovering RNA between both types of papers at 12-months storage, a statistic analysis was accomplished using $T$ student and Fisher test. CT values and positive/negative results for each repetition stored at $4^{\circ} \mathrm{C}$ and $-20^{\circ} \mathrm{C}$ were used for T Student test and Fisher test, respectively.

\section{Internal control to monitor nucleic acid extraction and PCR inhibitors.}

The efficiency of nucleic acid extraction and the presence of inhibitors for PCR amplification in semen and blood spotted in filter papers, fresh semen and tissue samples was checked by a PCR assay using a set of primers that specifically amplify a fragment of the constitutive bovine GAPDH gene. To accomplish that, GAPDH forward and reverse primer pair (Robinson et al., 2007) were used.

\section{Results}

\section{RT-qPCR standardization}

Regarding the primers' concentration adjustment, the best efficiency was observed in $470 \mathrm{nM}(0.47 \mu \mathrm{M})$ (101.86\%, slope: -3.389 ). The linear range of the PCR was from $2.5^{\star} 10^{9}$ to $2.5^{\star} 10^{1} \mathrm{DNA}$ copies $/ \mathrm{ml}$, with an efficiency of 2.02 and regression coefficient of 0.995. Based on the calculations made on the plasmid, the test detected 2.5 copies (LOD) (Fig. 1). Regarding the qPCR sensitivity for viral stocks, the qPCR amplified up to five copies of viral RNA. Among the sera and semen matrices, the test was able to detect up to 50 RNA copies (Table 1a). Also, the RT-qPCR test was able to detect a positive serum in a pool conformed of 30 bovine sera (Table $1 b$ ). 
Table 1

a. Number of copies detected by the qPCR in different matrixes: virus stock (Pestivirus B vs253), serum and semen straws. Results are expressed as 95\% agreement between 12 replicates. b. CT (Cycle Threshold) results for the different pool sizes evaluated.

\begin{tabular}{|c|c|c|c|c|}
\hline \multicolumn{5}{|l|}{ a } \\
\hline Target concentration (copies/mL) & Viral stock & \multicolumn{2}{|c|}{ Serum } & Semen straws \\
\hline 500,000 & + & \multicolumn{2}{|l|}{+} & + \\
\hline 50,000 & + & \multicolumn{2}{|l|}{+} & + \\
\hline 5.000 & + & \multicolumn{2}{|l|}{+} & + \\
\hline 500 & + & \multicolumn{2}{|l|}{+} & + \\
\hline 50 & + & \multicolumn{2}{|l|}{+} & + \\
\hline 5 & + & \multicolumn{2}{|c|}{ ND } & ND \\
\hline \multicolumn{5}{|l|}{ b } \\
\hline \multicolumn{3}{|c|}{ Pool size (number of individual sera within the pool) } & \multicolumn{2}{|l|}{ CT } \\
\hline 10 & \multicolumn{4}{|c|}{30.3} \\
\hline 20 & \multicolumn{4}{|c|}{30.7} \\
\hline 30 & \multicolumn{4}{|c|}{32.2} \\
\hline 40 & \multicolumn{4}{|c|}{ ND } \\
\hline 50 & \multicolumn{4}{|c|}{ ND } \\
\hline
\end{tabular}

In regard to specificity, the qPCR did not amplify the unrelated microorganisms (BRSV, PI-3, BHV-1, BHV-5, BTV, RVA and Mycoplasma spp.). Furthermore, the test was able to detect all bovine pestiviruses evaluated. Melting temperature (TM) values for each bovine pestiviral strain assayed is shown in Table 2, the specific range of TM was from 84.69 to $85.78^{\circ} \mathrm{C}$. The precision analysis on the $5^{\prime} \mathrm{UTR}$ plasmid and viral stocks showed relatively low standard deviation and little dispersion of CT results respect to the mean (Table 3). Concerning the inter-laboratory assays, it was possible to detect the plasmid in the three different laboratories using several cyclers, with CT values ranging from 13.92 to 22 . 
Table 2

TM (melting temperature) results for several bovine pestiviral strains assayed by the RT-qPCR.

\begin{tabular}{|c|c|}
\hline Strain & $\mathrm{TM}\left({ }^{\circ} \mathrm{C}\right)$ \\
\hline Bovine Pestivirus $A^{\text {a }}$ Singer & 85.41 \\
\hline Bovine Pestivirus Aa MF120553 & 85.50 \\
\hline Bovine Pestivirus A $A^{a} 88625$ & 85.78 \\
\hline Bovine Pestivirus $A^{a} 71267$ & 85.2 \\
\hline Bovine Pestivirus $A^{\mathrm{b}} 63588$ & 85.08 \\
\hline Bovine Pestivirus A 90611 & 85.59 \\
\hline Bovine Pestivirus A ${ }^{b}$ MF120552 & 85.10 \\
\hline Bovine Pestivirus A 59473 & 85.32 \\
\hline Bovine Pestivirus $A^{b} 83532$ & 85.62 \\
\hline Bovine Pestivirus $A^{b} 73611$ & 84.81 \\
\hline Bovine Pestivirus A A $^{\mathrm{b}}$ MF120594 & 85.22 \\
\hline Bovine Pestivirus $A^{b} 78256$ & 85.42 \\
\hline Bovine Pestivirus $A^{\mathrm{b}} 25366$ & 85.32 \\
\hline Bovine Pestivirus B 76/08 & 85.36 \\
\hline Bovine Pestivirus B vs253 & 85.59 \\
\hline Bovine Pestivirus B MF120585 & 85.44 \\
\hline Bovine Pestivirus B MF120586 & 85.61 \\
\hline Bovine Pestivirus H LV210185K/13 & 84.69 \\
\hline Bovine Pestivirus H MK017821 & 84.80 \\
\hline Bovine Pestivirus H MH992643 & 85.58 \\
\hline Bovine Pestivirus H \#48 & 85.1 \\
\hline Bovine Pestivirus H \#51 & 84.92 \\
\hline \multicolumn{2}{|c|}{ a Pestivirus A (formerly called BVDV-1) sub-genotype } \\
\hline
\end{tabular}


Table 3

Mean, standard deviation, repetitions number (n), weighted average variation coefficient (CVpp) and maximum random error allowed (CVa\%) of different repetitions of positive controls.

\begin{tabular}{|llllll|}
\hline & Mean & Standard deviation & $\mathbf{n}$ & CVpp & CVa\% \\
\hline 5'UTR Plasmid $\left(2,5.10^{3}\right.$ copies $)$ & 19.32 & 3.55 & 10 & 14.94 & 8.97 \\
\hline Pestivirus B vs253 (5.62.106 copies) & 14.69 & 3.07 & 25 & 9.61 & 5.76 \\
\hline
\end{tabular}

All clinical specimens collected from naturally infected animals which were positive to conventional gold standard methods (viral isolation followed by direct immunofluorescence) resulted positive when analyzed through the developed RT-qPCR, with CT values ranging from 15 to 35 (Online Resource 1).

Finally, GAPDH gene, which was used to monitor nucleic acid extraction and possible presence of PCR inhibitors in blood and semen spotted in filter papers, fresh semen and tissue samples, turned out positive in all runs, with TM results ranging from 80 to $81^{\circ} \mathrm{C}$ and homogeneous CT values $(20 \pm 3)$ for all specimens.

\section{Pestiviral detection in filter papers}

Filter papers spotted with spiked blood. As expected, when storage period increased, the RNA recovering percentage among repetitions decreased. For instance, one and 7-days storage of blood drops in chromatographic papers yielded higher recovery percentage respect to positive control CT when comparing with 6 and 12-months storage. Regarding storage temperatures, in general, $4^{\circ} \mathrm{C},-20^{\circ} \mathrm{C}$ and $-70^{\circ} \mathrm{C}$ were more effective in preserving RNA that RT, with a more marked trend as storage time increased (Table 4a). 
Table 4

CT (cycle threshold) means, number of positive determinations (PD) out of a total of 5 replicates, standard deviation (SD) and recovery percentage (Recovery \%) of 1-day, 7 days, 6 months and 12 months

repetitions at room temperature (RT), $4^{\circ} \mathrm{C},-20^{\circ} \mathrm{C}$ and $-70^{\circ} \mathrm{C}$ for spiked blood spotted in filter papers. $\mathbf{a}$.

results from chromatographic paper. b. results from FTA cards.

\begin{tabular}{|c|c|c|c|c|c|c|c|c|c|c|c|c|}
\hline a & RT & & & $4^{\circ} \mathrm{C}$ & & & $-20^{\circ} \mathrm{C}$ & & & $-70^{\circ} \mathrm{C}$ & & \\
\hline & $\begin{array}{l}\text { CT } \\
\text { mean }\end{array}$ & PD & SD & $\begin{array}{l}\mathrm{CT} \\
\text { mean }\end{array}$ & PD & SD & $\begin{array}{l}\text { CT } \\
\text { mean }\end{array}$ & PD & SD & $\begin{array}{l}\text { CT } \\
\text { mean }\end{array}$ & PD & SD \\
\hline 1 day & 27.14 & 5 & 2.09 & 25.58 & 4 & 0.57 & 25.64 & 5 & 1.98 & 27.23 & 4 & 1.78 \\
\hline $\begin{array}{l}\text { Recovery } \\
\%\end{array}$ & 84.16 & & & 89.29 & & & 89.08 & & & 83.88 & & \\
\hline 7 days & 28,77 & 5 & 4.67 & 28.67 & 5 & 0.99 & 28,47 & 5 & 1.12 & 26.26 & 5 & 2.12 \\
\hline $\begin{array}{l}\text { Recovery } \\
\%\end{array}$ & 79.39 & & & 79.67 & & & 80.22 & & & 86.98 & & \\
\hline $\begin{array}{l}6 \\
\text { months }\end{array}$ & 32.1 & 3 & 1.18 & 25.12 & 3 & 1.73 & 24.83 & 5 & 0.84 & 22,02 & 5 & 0.99 \\
\hline $\begin{array}{l}\text { Recovery } \\
\%\end{array}$ & 48.35 & & & 61.78 & & & 62.51 & & & 57.67 & & \\
\hline $\begin{array}{l}12 \\
\text { months }\end{array}$ & ND & 0 & - & 27 & 4 & 0.6 & 26.87 & 4 & 0.96 & & NP & \\
\hline $\begin{array}{l}\text { Recovery } \\
\%\end{array}$ & 0 & & & 67.81 & & & 68.14 & & & & & \\
\hline \multirow[t]{2}{*}{ b } & RT & & & $4^{\circ} \mathrm{C}$ & & & $-20^{\circ} \mathrm{C}$ & & & $-70^{\circ} \mathrm{C}$ & & \\
\hline & $\begin{array}{l}\text { CT } \\
\text { mean }\end{array}$ & PD & SD & $\begin{array}{l}\text { CT } \\
\text { mean }\end{array}$ & PD & SD & $\begin{array}{l}\text { CT } \\
\text { mean }\end{array}$ & PD & SD & $\begin{array}{l}\text { CT } \\
\text { mean }\end{array}$ & PD & SD \\
\hline $\begin{array}{l}12 \\
\text { months }\end{array}$ & ND & 0 & - & 27.11 & 3 & 0.55 & 28.52 & 3 & 8.78 & & NP & \\
\hline $\begin{array}{l}\text { Recovery } \\
\%\end{array}$ & 0 & & & 67.81 & & & 64.20 & & & & & \\
\hline \multicolumn{13}{|c|}{$\mathrm{ND}=$ not detected. } \\
\hline$N P=$ not & sec & & & & & & & & & & & \\
\hline
\end{tabular}

When analyzing the samples stored for 12 months, results were similar in both types of papers (chromatographic paper and FTA cards) at $4^{\circ} \mathrm{C}$ and $-20^{\circ} \mathrm{C}$ storage temperatures (Table $4 \mathrm{~b}$ ). No significative differences were noted between both types of papers at 12 months storage at $4^{\circ} \mathrm{C}(\mathrm{p}=0.865)$ and at $-20^{\circ} \mathrm{C}(p=0.776)$ using $T$ Student test, neither at $4^{\circ} \mathrm{C}(p=0.500)$ and at $-20^{\circ} \mathrm{C}(p=0.500)$ using Fisher test.

Unfortunately, it was not possible to process the samples stored at $-70^{\circ} \mathrm{C}$. At 18 months, results were negative for all storage temperature variables in both types of papers. 
Limit of detection in chromatographic paper. Regarding the LOD in blood samples, the qPCR was able to detect up to 1,000 copies of viral RNA (Table 5).

Table 5

Results for spiked blood spotted in

chromatographic paper at several target

concentrations. Results are expressed as $95 \%$

agreement between 12 replicates.

\begin{tabular}{|ll|}
\hline Target concentration (copies/mL) & Blood \\
\hline 80,000 & + \\
40,000 & + \\
\hline 20,000 & + \\
10,000 & + \\
\hline 5,000 & + \\
\hline 1,000 & + \\
\hline 100 & $N D$ \\
\hline$N D=$ not detected. & \\
\hline
\end{tabular}

Recovering RNA in papers from clinical samples. Blood drops from two $\mathrm{PI}$ animals spotted in chromatographic paper and stored for one day and 6 and 12 months at $4^{\circ} \mathrm{C}$ yielded positive by the developed RT-qPCR, suggesting that after one year of storage at $4^{\circ} \mathrm{C}$, there was no significant degradation of the viral RNA on the chromatographic paper for both PI animals (Fig. 2). On the contrary, results were negative at 18-months storage time.

\section{Discussion}

The developed RT-qPCR was able to detect the viral RNA in all bovine pestiviral strains tested and showed high specificity. A major advantage, is the ability to detect Pestivirus $\mathrm{H}$ strains, which can be useful in areas where Pestivirus $\mathrm{H}$ are co-circulating with Pestivirus $\mathrm{A}$ and $\mathrm{B}$. Further, complete agreement was observed between RT-qPCR and viral isolation results of all clinical samples tested. In pooled sera, the test was able to detect a positive animal among 30 sera, which means a significant advantage when carrying out BVD control in low-prevalence herds since it allows reducing the number of assays. However, in herds where BVDV prevalence is high, there is an increased chance that any single pool will test positive if pool size is too large, requiring additional testing to identify the viremic individuals (Muñoz-Zanzi et al., 2000; Smith et al., 2008). Thus, prevalence estimation should be considered when laboratories use the poolingstrategy, especially in regions with high BVD prevalence (Emmanuel et al., 1988). Also, when the pool contains a large number of individual samples, the dilution effect can cause false negatives. This research has provided an in-house validated RT-qPCR that can replace commercially available kits, which 
represent a great cost in trading for some countries, and can be useful for veterinary diagnostic laboratories equipped with the infrastructure to perform qPCR assays.

Because of the SYBR Green-based detection system, the developed RT-qPCR presents some advantages: it is sensitive, easy to use and inexpensive. However, it is important to recognize the presence of any doublestranded DNA (e.g., primer-dimers) that can cause false positive results. This inconvenient can be sorted including an analysis after the amplification run, using the melting temperature of the expected amplicon, which allows the discrimination of the target amplicon to undesired products that can interfere with the results (Ririe et al., 1997). Also, using One-Step for retro-transcription and PCR reaction simultaneously reduces the costs, time-consumed and possibilities of contamination of the assay.

Diagnostic laboratories routinely use blood or serum for BVD analyses. In terms of practicability in the use of filter papers at the point of care, whole blood is more suitable than serum since it avoids the centrifugation step. Although semen is not used as a sample of choice to diagnose bovine pestiviruses, it is useful for the control of BVD in breeding herds (Saliki and Dubovi, 2004), however, our group tested the same methodology using semen straw samples spotted in filter papers without achieving satisfactory results (Online Resource 2).

To the best of our knowledge, just two studies were published about preserving bovine pestiviral RNA by using solid carriers. The first article used several filter papers to preserve RNA up to six months in blood and sera samples from PI animals at RT, $4^{\circ} \mathrm{C}$ and $-18^{\circ} \mathrm{C}$ (Vilcek et al., 2001). In this study, the authors evaluated four different types of papers: classical filter papers, Whatman paper No. 1, nitrocellulose membrane and HYBOND ${ }^{\mathrm{TM}}$-M nylon membrane. Results were similar for all papers tested except for classical filter papers, which yielded lower PCR products. However, the authors used an end-point RT-PCR assay and RNA isolation was carried out directly from filter papers, avoiding the elution step.

Unfortunately, that strategy did not yield good results in our experiments (data not shown). Another study was reported in FTA cards for the detection of several viral agents involved in the bovine respiratory complex, including bovine pestivirus, where viral RNA from respiratory tract swabs was stored 14 days at temperatures between -27 and $46^{\circ} \mathrm{C}$. The article compared the RNA recovery from specimens in viral transport medium and FTA fixed samples, which proved $100 \%$ agreement (Liang et al., 2014). Unlike the former, in this paper authors used a qPCR assay and carried out an elution protocol before RNA extraction.

Our study suggests that chromatographic papers are a useful alternative for collecting and shipping blood samples for BDV diagnostic purposes, as a cost-effective method. However, for longer storage time (6 and 12 months), the recovery percentages decreased, although RNA was still detected, meaning that the biobanking purposes are not suitable for more than 12 months storage at any temperature with the protocols evaluated in this experiment. Nevertheless, the fact that pestiviral RNA was amplified in PI animals' blood stored up to 12 months in chromatographic paper, suggests that, although the recovery percentage was lower as storage time progressed, it was still possible to recover RNA in blood samples from $\mathrm{PI}$ animals kept at refrigeration temperature. 
FTA cards contain chelating agents and a free-radical trap designed to deal with atmospheric pollutants, thus protecting the entrapped nucleic acids for at least six years at room temperature (Ahmed et al., 2011). However, in our work, chromatographic paper -which lacks these components-, yielded similar results. Moreover, for 12 months storage, drops spotted in chromatographic paper showed slightly better results than in FTA cards, considering the number of positive repetitions.

When collecting samples, we recommend drying the drop spotted in filter papers at room temperature for at least four hours (depending on ambient humidity), and sending to the laboratory in individual zipped bags with a desiccant, like silica gel. For shipping, refrigeration is not necessary.

The possibility to store viral nucleic acids in filter papers means a breakthrough in veterinary practice. The chance to collect samples directly in filter papers from herds where the disease is suspected could be very helpful, since in this kind of matrix, samples do not require immediately shipping or refrigeration and more important, they do not need to be processed instantly (Choi et al., 2014). This methodology is mostly advantageous when performing molecular studies, since it guarantees nucleic acid stability at a wide range of temperatures and filter papers can be used with a variety of samples. Comparing with the traditional method for collecting, shipping and storing samples, filter papers methodology represents a major improvement specially in large countries with poor infrastructure for shipping samples and also for those which lack laboratories who run this type of assays in every state or province.

An advantage of using chromatographic paper as a method for collecting samples is its cost. Every sheet of paper can hold approximately 25 drops of sample, with a value of USD 66.55 per 100 sheets. In contrast, only four drops of sample can be spotted in every FTA card, with an approximated cost of USD 308 (depending on the provider) per 25 sheets.

Our study demonstrated that an economical filter paper, like chromatographic paper, is an appropriate alternative for collecting, shipping and storing blood samples for BVD diagnosis, giving results as good as using FTA specialized cards. The aforementioned is valid, as long as it is accompanied by a highly sensitive technique as the RT-qPCR reported in this study.

Further studies using this methodology applied to other viruses are granted, especially for diseases relevant to bovine health, which require mandatory control and are economically important for local production in order to improve sampling, shipping and laboratory processing conditions.

\section{Declarations}

\section{Funding}

Financial support for the execution of this study was provided by Fundación Argeninta.

\section{Author contributions}


All authors contributed to the study conception and design. Conceptualization and supervision were carried out by María José Dus Santos, Luis Calvinho and Andrea Pecora. Material preparation, data collection and analysis were performed by Paula Favaro and Andrea Pecora. Statistical analysis was performed by Ana Molineri. The first draft of the manuscript was written by Paula Favaro and Andrea Pecora and all authors commented on previous versions of the manuscript. All authors read and approved the final manuscript.

\section{Ethics approval}

Approval regarding the collection and handling of clinical specimens was obtained from the Ethics and Safety Advisory Committee from Litoral's National University (protocol number: 576/20).

\section{Conflict of interest}

The authors declared no conflict of interest with respect to the research, authorship, and/or publication of this article.

\section{Consent to participate}

All authors participated voluntarily in the research.

\section{Consent for publication}

All authors read and approved the final manuscript. All authors gave their consent for research publication.

\section{Data availability}

All data generated or analyzed during this study are included in this published article and its supplementary information files.

\section{References}

1. Ahmed, H.A., MacLeod, E.T., Hide, G., Welburn, S.C., Picozzi, K., (2011). The best practice for preparation of samples from FTA®cards for diagnosis of blood borne infections using African trypanosomes as a model system. Parasites and Vectors, 4:1-7. https://doi.org/10.1186/1756-33054-68

2. Brock, K.V., Grooms, D.L., Ridpath, J., Bolin, S.R., (1998). Changes in levels of viremia in cattle persistently infected with bovine viral diarrhea virus. Journal of Veterinary Diagnostic Investigation, 10:22-26. https://doi.org/10.1177/104063879801000105

3. Bustin, S.A., Benes, V., Garson, J.A., Hellemans, J., Huggett, J., Kubista, M., Mueller, R., Nolan, T., Pfaff, M.W., Shipley, G.L., (2009). The MIQE Guidelines: Minimum Information for Publication of 
Quantitative Real-Time PCR Experiments. Clinical Chemistry, 55:1-12.

https://doi.org/10.1373/clinchem.2008.112797

4. Choi, E.H., Lee, S.K., Ihm,C., Sohn, Y.H., (2014). Rapid DNA Extraction from Dried Blood Spots on Filter Paper: Potential Applications in Biobanking. Osong Public Health and Research Perspectives, 5:351357. https://doi.org/10.1016/j.phrp.2014.09.005

5. Dubovi, E.J., (2013). Laboratory diagnosis of bovine viral diarrhea virus. Biologicals, 41:8-13. https://doi.org/10.1016/j.biologicals.2012.06.004

6. Emmanuel, J.C., Bassett, M.T., Smith, H.J., Jacobs, J.A., (1988). Pooling of sera for human immunodeficiency virus (HIV) testing: An economical method for use in developing countries. Journal of Clinical Pathology, 41:582-585. https://doi.org/10.1136/jcp.41.5.582

7. Ivanovaa, S., Angelovab, S., Golkocheva-Markovac, E., Genova-Kaloud, E., Pavlovae, A., Georgieva, I., (2017). A Review on Dried Blood Spots (DBS) as Alternative, Archival Material for Detection of Viral Agents (Measles, Mumps, Rubella, Hepatitis B Virus). American Academic Scientific Research Journal for Engineering, Technology and Sciences, 30:161-172.

8. Lértora, W.J., (2003). Diarrea viral bovina: actualización. Revista Veterinaria, 14:42-51.

9. Liang, X., Chigerwe, M., Hietala, S.K., Crossley, B.M., (2014). Evaluation of Fast Technology Analysis (FTA) Cards as an improved method for specimen collection and shipment targeting viruses associated with Bovine Respiratory Disease Complex. Journal of Virological Methods, 202:69-72. https://doi.org/10.1016/j.jviromet.2014.02.022

10. Lindberg, A., Brownlie, J., Gunn, G.J., Houe, H., Moennig, V., Saatkamp, H.W., Sandvik, T., Valle, P.S., (2006). The control of bovine viral diarrhoea virus in Europe: Today and in the future. Revue scientifique et technique, 25:961-979. https://doi.org/10.20506/rst.25.3.1703

11. Littledike, E.T., Bolin, S.R., Ridpath, J.F., (1993). Consequences of Antigenic Diversity of Bovine Viral Diarrhea Virus. Beef Research Progress Report 4:179-182.

12. Meyling, A., Mikél Jensen, A., (1988). Transmission of bovine virus diarrhoea virus (BVDV) by artificial insemination (Al) with semen from a persistently-infected bull. Veterinary Microbiology, 17:97-105. https://doi.org/10.1016/0378-1135(88)90001-6

13. Moenning, V., Becher, P., (2015). Pestivirus control programs: how far have we come and where are we going? Animal Health Research Reviews, 16:83-87 doi:10.1017/S1466252315000092

14. Monteiro, F.L., Cargnelutti, J.F., Martins, B., Noll, J.G., Weiblen, R., Flores, E.F., (2019). Detection of bovine pestiviruses in sera of beef calves by a RT-PCR based on a newly designed set of pan - bovine pestivirus primers. Journal of Veterinary Diagnostic Investigation, 31:255-258.

https://doi.org/10.1177/1040638719826299

15. Moscoso, H., Alvarado, I., Hofacre, C.L., (2006). Molecular Analysis of Infectious Bursal Disease Virus from Bursal Tissues Collected on FTA® Filter Paper. Avian Diseases, 50:391-396. https://doi.org/10.1637/7505-011306r.1

16. Muñoz-Zanzi, C.A., Johnson, W.O., Thurmond, M.C., Hietala, S.K., (2000). Pooled-sample testing as a herd-screening tool for detection of bovine viral diarrhea virus persistently infected cattle. Journal of 
Veterinary Diagnostic Investigation, 12:195-203. https://doi.org/10.1177/104063870001200301

17. Muthukrishnan, M., Singanallur, N.B., Ralla, K., Villuppanoor, S.A., (2008). Evaluation of FTA® cards as a laboratory and field sampling device for the detection of foot-and-mouth disease virus and serotyping by RT-PCR and real-time RT-PCR. Journal of Virological Methods, 151:311-316. https://doi.org/10.1016/j.jviromet.2008.05.020

18. Perozo, F., Villegas, P., Estevez, C., Alvarado, I., Purvis, L.B., (2006). Use of FTA® filter paper for the molecular detection of Newcastle disease virus. Avian Pathology 35:93-98. https://doi.org/10.1080/03079450600597410

19. Picard-Meyer, E., Barrat, J., Cliquet, F., (2007). Use of filter paper (FTA®) technology for sampling, recovery and molecular characterisation of rabies viruses. Journal of Virological Methods, 140:174182. https://doi.org/10.1016/j.jviromet.2006.11.011

20. Ririe, K.M., Rasmussen, R.P., Wittwer, C.T., (1997). Product differentiation by analysis of DNA melting curves during the polymerase chain reaction. Analytical Biochemistry, 245:154-160. https://doi.org/10.1006/abio.1996.9916

21. Robinson, T.L., Sutherland, I.A., Sutherland, J., (2007). Validation of candidate bovine reference genes for use with real-time PCR. Veterinary Immunology and Immunopathology, 115:160-165. https://doi.org/10.1016/j.vetimm.2006.09.012

22. Rondón, I., (2006). Diarrea viral bovina: patogénesis e inmunopatología. Revista MVZ Córdoba, 11:694-704.

23. Sakai, T., Ishii, A., Segawa, T., Takagi, Y., Kobayashi, Y., Itou, T. (2015). Establishing conditions for the storage and elution of rabies virus RNA using FTA® cards. Journal of Veterinary Medical Science, 77:461-465. https://doi.org/10.1292/jvms.14-0227

24. Saliki, J.T., Dubovi, E.J., (2004). Laboratory diagnosis of bovine viral diarrhea virus infections. Veterinary Clinics of North America - Food Animal Practice, 20:69-83. https://doi.org/10.1016/j.cvfa.2003.11.005

25. Sambrook, J., Russell, D., (2006). Quantitative PCR. Cold Spring Harbor Protocols, 2006:503-509. https://doi.org/10.1101/PDB.PROT3842

26. Sandvik, T., (1999). Laboratory diagnostic investigations for bovine viral diarrhoea virus infections in cattle. Veterinary Microbiology, 64:123-134. https://doi.org/https://doi.org/10.1016/S03781135(98)00264-8

27. Sarangi, L.N., Naveena, T., Rana, S.K., Surendra, K.S.N.L., Reddy, R.V.C., Bajibabu, P., Ponnanna, N.M., Sharma, G.K., Srinivasan, V.A., (2018). Evaluation of a specialized filter-paper matrix for transportation of extended bovine semen to screen for bovine herpesvirus- 1 by real-time PCR. Journal of Virological Methods, 257:1-6. https://doi.org/10.1016/j.jviromet.2018.03.009

28. Schirrmeier, H., Strebelow, G., Depner, K., Hoffmann, B., Beer, M., (2004). Genetic and antigenic characterization of an atypical pestivirus isolate, a putative member of a novel pestivirus species. Journal of General Virology, 85:3647-3652. https://doi.org/10.1099/vir.0.80238-0 
29. Smith, D.B., Meyers, G., Bukh, J., Gould, E.A., Monath, T., Muerhoff, A.S., Pletnev, A., Rico-Hesse, R., Stapleton, J.T., Simmonds, P., Becher, P., (2017). Proposed revision to the taxonomy of the genus Pestivirus, family Flaviviridae. Journal of General Virology, 98:2106-2112. https://doi.org/10.1099/jgv.0.000873

30. Smith, R.L., Sanderson, M.W., Walz, P.H., Givens, M.D., (2008). Sensitivity of polymerase chain reaction for detection of bovine viral diarrhea virus in pooled serum samples and use of pooled polymerase chain reaction to determine prevalence of bovine viral diarrhea virus in auction market cattle. Journal of Veterinary Diagnostic Investigation, 20:75-78. https://doi.org/10.1177/104063870802000115

31. Ståhl, K., Alenius, S., (2012). BVDV control and eradication in Europe-an update. Japanese Journal of Veterinary Research, 60:31-39. https://doi.org/10.14943/jjvr.63.1.15

32. Valley, M., (2017). Flaviviridae. In: Fenner's Veterinary Virology, 5th ed. Elsevier, London, pp 525-545

33. Vilcek, S., Strojny, L., Durkovic, B., Rossmanith, W., Paton, D., (2001). Storage of bovine viral diarrhoea virus samples on filter paper and detection of viral RNA by a RT-PCR method. Journal of Virological Methods, 92:19-22.

\section{Figures}

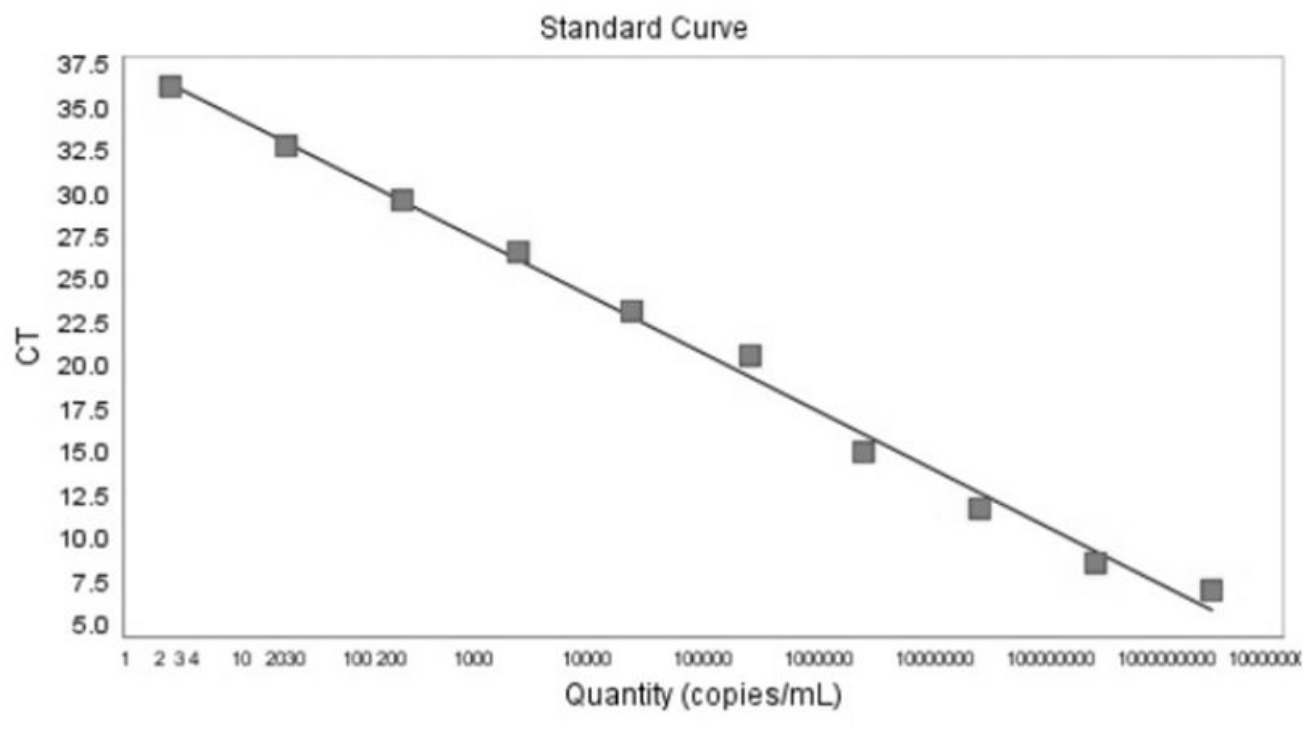

\begin{tabular}{lll}
\hline \multicolumn{3}{c}{ 5'UTR plasmid } \\
\hline $\begin{array}{l}\text { Target } \\
\text { concentration } \\
\text { (copies/mL) }\end{array}$ & CT & TM \\
\hline $2,500,000,000$ & 6.94 & 85.16 \\
$250,000,000$ & 8.52 & 84.88 \\
$25,000,000$ & 11.75 & 84.93 \\
$2,500,000$ & 14.98 & 84.81 \\
250,000 & 20.59 & 84.86 \\
25,000 & 23.16 & 84.95 \\
2,500 & 26.56 & 85.06 \\
250 & 29.58 & 85.03 \\
25 & 32.81 & 84.95 \\
2.5 & 36.13 & 84.88 \\
0.25 & ND & ND \\
\hline \multicolumn{3}{l}{} \\
\end{tabular}

\section{Figure 1}

Left: Plasmid linear range of detection by the developed qPCR. Right: CT (Cycle threshold) and TM (Melting temperature in ${ }^{\circ} \mathrm{C}$ ) values for 10 -folded dilutions of the $5^{\prime}$ UTR plasmid. ND= not detected Created with Microsoft Power Point 


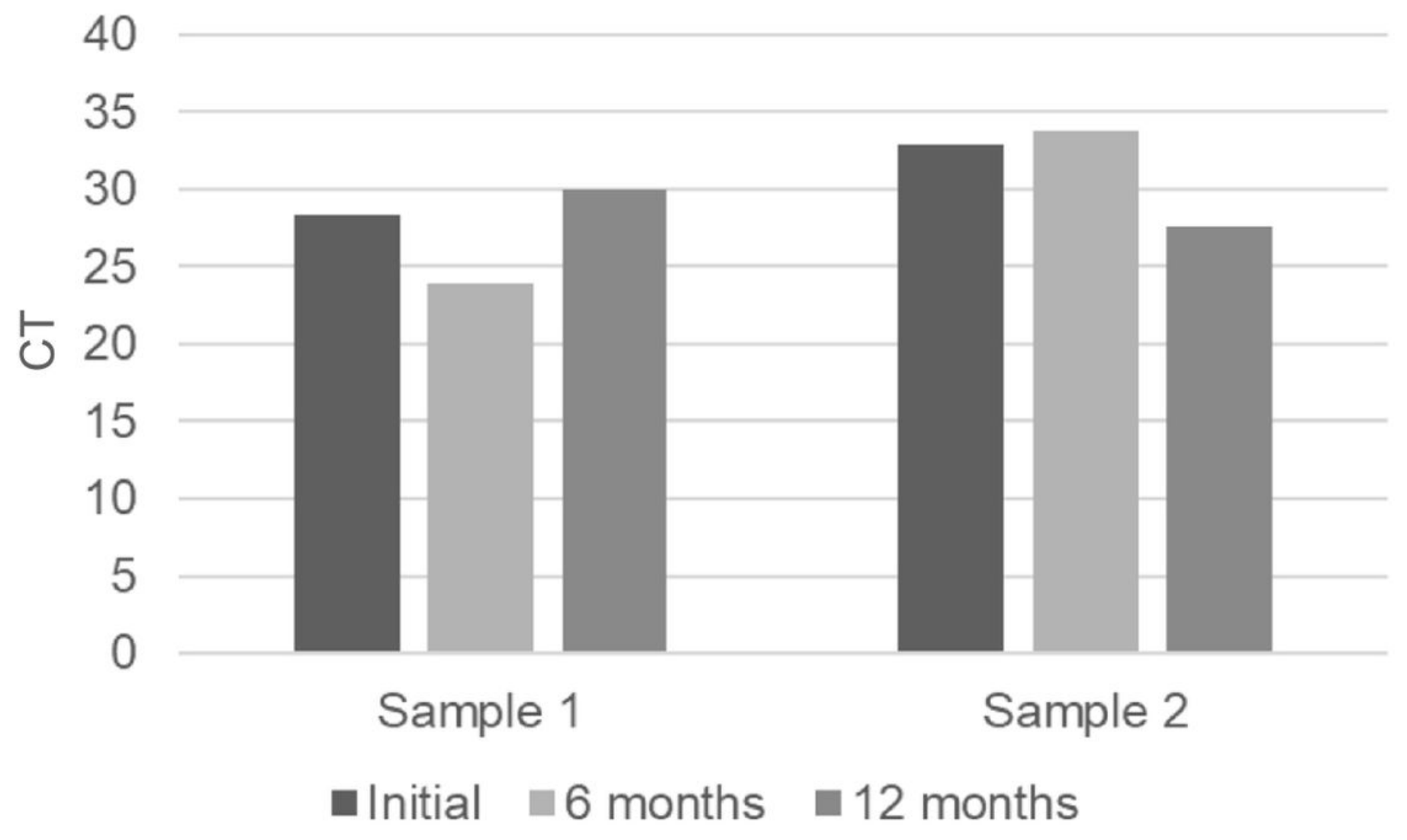

\section{Figure 2}

CT (cycle threshold) values of blood from two PI animals spotted in chromatographic paper after 1-day (initial), 6 and 12-months storage at $4^{\circ} \mathrm{C}$

Created with Microsoft Excel

\section{Supplementary Files}

This is a list of supplementary files associated with this preprint. Click to download.

- ESM1.pdf

- ESM2.pdf 